\title{
EFFECT OF INFILL WALLS ON THE SEISMIC PERFORMANCE OF THE MULTISTORIED BUILDINGS
}

\author{
Lini M Thomas ${ }^{1}$, Kavitha P.E. ${ }^{2}$ \\ ${ }^{1}$ (M.Tech Computer Aided Structural Engineering, SNGCE, Ernakulam, Kerala, India) \\ ${ }^{2}$ (Assoc. Prof., Department of Civil Engineering, SNGCE, Ernakulam, Kerala, India)
}

\begin{abstract}
The most commonly used structural system in our country for almost all types of building are multi-storey reinforced concrete frames with masonry infills. Therefore it is essential to understand the seismic behaviour of these structures when subjected to lateral forces. Several research works has been done on the masonry infilled reinforced concrete frames in the past decades. Mortar is used as a binder in normal brick construction in order to create continuous structural form and to bind together the individual units in brickwork. In the present study, analysis has been carried out by considering the increase in height of building from five to ten storied by using finite element software ANSYS 14.5. The seismic analysis of multi-storeyed building frames with infill walls and without infill walls are conducted. $3 D$ analysis will give more realistic values of deflection and stresses. Since this type of study is not feasible in terms of analysis time taken, $2 D$ model was adopted for the present study. A three bay two dimensional building frame is considered with the number of stories varying from 5 storied to 10 storied. The loading applied is as per IS 1893 (Part I): 2002. Equivalent diagonal strut method is adopted for modelling infill walls. The results showed that there is considerable decrease in deflection when infills are used in RC frames.
\end{abstract}

Key Words: Deflection, Equivalent diagonal strut method, lateral load, Solid brick infills, Storey drift

\section{INTRODUCTION}

Infill wall panels are used in framed building to create building façade or envelope. Also to subdivide the internal spaces of the building. Infills in frames reduce the lateral deflection of the building. The IS code provisions do not give any guidelines for the analysis of RC frames with infill wall. The masonry infill panels in buildings generally are not considered for the design process and may be treated as non structural or architectural components. But, the presence of masonry infill panels has a great significant impact on the seismic response of the RC framed building. The presence of infill walls reduces lateral deflections and thereby reducing probability of the collapse.

\subsection{Equivalent Diagonal Strut Method}

From previously conducted several studies it showed that Equivalent diagonal strut method can be used for modeling the brick infill wall to easily represent the effect of inplane action during lateral load. Infill walls are analytically replaced by equivalent diagonal struts [3]. Considering single diagonal strut for modelling infill and it carries only compression forces. The end points of the strut connected to the frame is pin jointed to avoid the moment from frame to infill. In this method the infill wall is idealized as diagonal strut and the frame is modelled as beam or truss element. The idealization is based on the assumption that there is no bond between frame and infill.

The width of the diagonal strut is given as

Where,

$$
\mathrm{w}=0.175\left(\lambda^{\prime} \mathrm{h}\right)^{-0.4} \mathrm{~d}^{\prime}
$$

Contact length parameter $\left(\lambda^{\prime}\right)=$

$$
\sqrt[4]{\frac{E f t \sin (2 \theta)}{4 E i I c h}}
$$

$E_{i}=$ modulus of elasticity of the infill material

$\mathrm{E}_{\mathrm{f}}=$ modulus of elasticity of the frame material

$\mathrm{L}=$ beam length between centre lines of the columns

$\mathrm{h}=$ column height between centre lines of the beams

$h^{\prime}=$ height of the infill wall

$\mathrm{t}=$ thickness of the infill wall

$\mathrm{d}^{\prime}=$ diagonal length of the strut

$\theta=$ angle between the diagonal of infill panel and the horizontal in radians

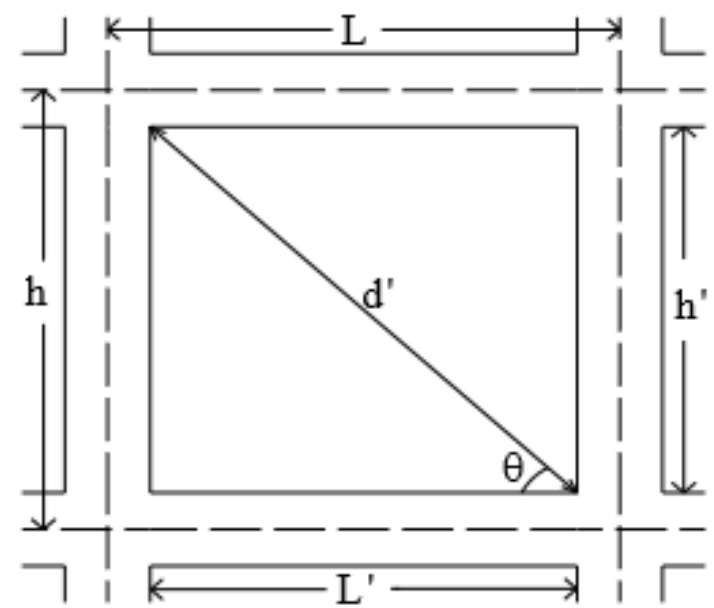

Fig -1: Diagonal strut modelling method of the infill panel 


\section{FINITE ELEMENT ANALYSIS}

\subsection{Material Properties of the Model}

\section{Material properties of Concrete}

Type of material - Isotropic

Weight per volume, Density $=25 \mathrm{kN} / \mathrm{m}^{3}$

Compressive strength $=25 \mathrm{~N} / \mathrm{m}^{2}$

Modulus of Elasticity $=22000 \mathrm{~N} / \mathrm{mm}^{2}$

Poissons ratio $=0.15$

\section{Material properties of Solid Brick infill}

Type of material - Isotropic

Weight per volume, Density $=20 \mathrm{kN} / \mathrm{m}^{3}$

Compressive strength $=12 \mathrm{~N} / \mathrm{m}^{2}$

Modulus of Elasticity $=8280 \mathrm{~N} / \mathrm{mm}^{2}$

Poissons ratio $=0.16$

\subsection{Choosing Element Type}

In order to analyse the model, it is required to specify an adequate element type for mesh generation in ANSYS 14.5. Here the element used is BEAM 188 for modelling the beams and columns and LINK 180 for modelling the diagonal struts.

\subsection{Modelling and Meshing of the Model}

The RC frames are fully modelled in software using key points at every corners. The key points are then connected together by means of straight lines. Following datas are used in the analysis of the RC framed building models.

Size of beam : $300 \times 300 \mathrm{~mm}$

Size of Column : 300 x $300 \mathrm{~mm}$

Spacing between frames : $3500 \mathrm{~mm}$

Height of the storey : $3.5 \mathrm{~m}$

The finite element discretization was done by using line meshing.

\subsection{Applying Boundary Conditions}

The frames are fixed at the bottom. All the degrees of freedom of the displacement are restrained against movement .

\subsection{Applying Loading Conditions}

Loading is done as per IS 1893 (Part I): 2002.The total lateral force or design seismic base shear is calculated by using expression

$$
\mathrm{V}_{\mathrm{B}}=\mathrm{A}_{\mathrm{h}} \mathrm{W} \quad \text { (Clause 7.5.3) }
$$

$\mathrm{V}_{\mathrm{B}}=$ Design seismic base shear as per IS 1893(Part I): 2002

$\mathrm{A}_{\mathrm{h}}=$ Design horizontal acceleration spectrum value

The design horizontal seismic coefficient $A_{h}$ shall be determined by the following expression

(Clause 6.4.2)

$A h=\frac{Z I S a}{2 R g}$

Where,

$\mathrm{Z}$, Zone factor $=0.16$

I, Importance factor $=1$
$\mathrm{Sa} / \mathrm{g}$, Average response acceleration coefficient $=2.5$

(Clause 6.4.1)

Seismic zone : III

Type of frame : Ordinary RC moment resisting frame

$\mathrm{R}$, Response reduction factor $=3$

Design lateral force at $i^{\text {th }}$ floor may be calculated by

(Clause 7.7.1)

$$
Q_{\mathrm{i}}=V_{\mathrm{B}} \frac{W_{\mathrm{i}} h_{\mathrm{i}}{ }^{2}}{\sum_{j=1}^{n} W_{\mathrm{j}} h_{\mathrm{j}}{ }^{2}}
$$

$\mathrm{Q}_{\mathrm{i}}=$ Design lateral force at floor $\mathrm{i}$

$\mathrm{W}_{\mathrm{i}}=$ Seismic weight of floor $\mathrm{i}$

$h_{i}=$ Height of floor i measured from base

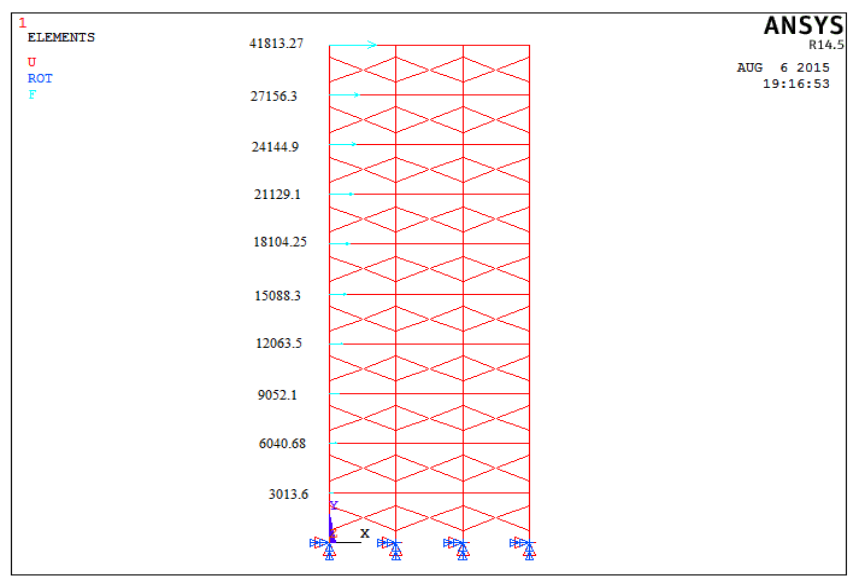

Fig -2: Ten storied frame by applying loading condition

\subsection{Analysis of the Models}

For the analysis static non linear analysis is performed on the models. Nonlinear analysis is the method used for determining the earthquake response of the structural systems.

\section{RESULTS}

In this study, the effect of solid brick infill walls on the seismic performance of the multistoried buildings are studied in detail. A comparative study is carried out on 2D infill framed structures with solid and bare frame as the height of the building increases. The effects of infills on the maximum displacement of the frames with medium to high rise buildings are considered for the analysis. Deflections are one of the most important parameter to be considered in the design and analysis of a tall building. Therefore deflections for Earthquake loads have been studied according to equivalent strut method for different cases and comparisons are made. The 6 cases adopted for the modelling are

1.) 3 bay 10 storied $2 \mathrm{D}$ frames with solid and bare frames

2.) 3 bay 9 storied $2 \mathrm{D}$ frames with solid and bare frames

3.) 3 bay 8 storied $2 \mathrm{D}$ frames with solid and bare frames

4.) 3 bay 7 storied $2 \mathrm{D}$ frames with solid and bare frames

5.) 3 bay 6 storied $2 \mathrm{D}$ frames with solid and bare frames

6.) 3 bay 5 storied $2 \mathrm{D}$ frames with solid and bare frames

The following parameters are discussed like lateral displacement and Storey drift 


\subsection{Lateral Displacements}

It is the displacements caused by the Lateral Force on each storey level of the structure. Lateral displacements will be more on top storeys. Hence after analyzing each buildings, the results obtained for different models and the comparisons are presented in tabular form.

\subsection{Storey Drift}

It is the displacement of one storey level with respect to the next level above or below. As per IS 1893 (Part 1):2002, the storey drift shall not exceed 0.004 times the storey height. The inter storey drift is one of the commonly used damage parameter. The inter storey drift is defined as

$\frac{\delta i-\alpha i}{h i}$

Where,

$(\delta i-\alpha i)$ is the relative displacement between successive storey and $h i$ is the storey height

\section{COMPARISON OF RESULTS}

\subsection{Comparison of Maximum Deflection in A 3 Bay}

\section{Storied Building With And Without Infills}

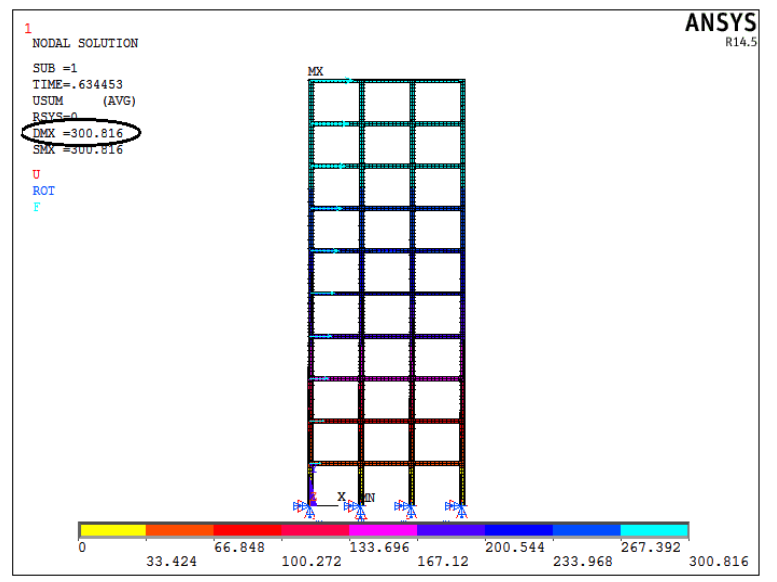

Fig -3: Maximum deflection in ten storied bare frame

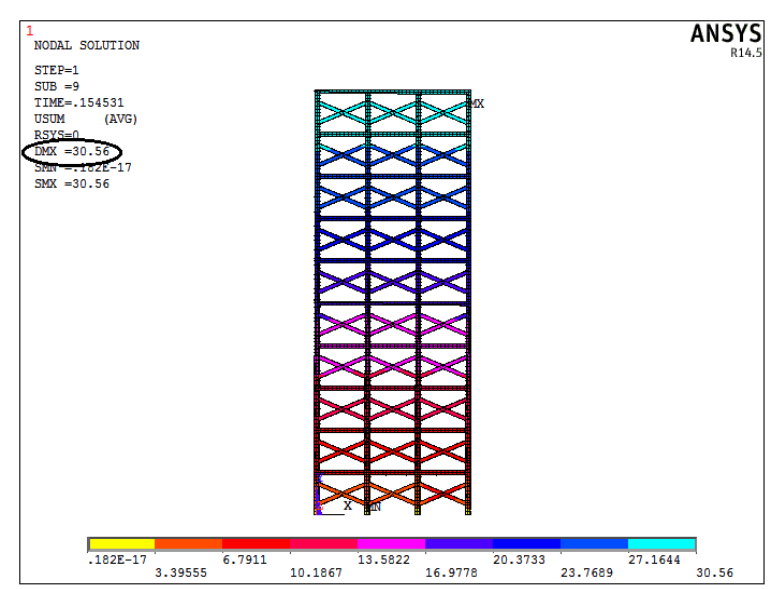

Fig -4: Maximum deflection in ten storied frame with infills
Table -1: Comparison of maximum deflection in each

\begin{tabular}{|c|c|c|c|}
\hline $\begin{array}{c}\text { Store } \\
\text { No. }\end{array}$ & $\begin{array}{c}\text { Maximum } \\
\text { deflection } \\
\text { in bare } \\
\text { frame }\end{array}$ & $\begin{array}{c}\text { Maximum } \\
\text { deflection in } \\
\text { building with } \\
\text { solid brick } \\
\text { infills ( mm) }\end{array}$ & $\begin{array}{c}\text { \% decrease in } \\
\text { deflection of } \\
\text { SBIW with } \\
\text { reference to } \\
\text { Bare frame }\end{array}$ \\
\hline 10 & 300.816 & 30.56 & 29 \\
\hline 9 & 283.1 & 28.32 & 33.15 \\
\hline 8 & 261.2 & 26.19 & 36.65 \\
\hline 7 & 243.9 & 24.2 & 42.10 \\
\hline 6 & 203.1 & 19.96 & 36.62 \\
\hline 5 & 172.4 & 14.32 & 27.33 \\
\hline 4 & 145.76 & 11.91 & 22.51 \\
\hline 3 & 118.1 & 9.11 & 19.64 \\
\hline 2 & 95.45 & 7.32 & 33.06 \\
\hline 1 & 53.24 & 5.92 & 59.29 \\
\hline
\end{tabular}

Table -2: Storey drift in a 10 storied frame

\begin{tabular}{|c|c|}
\hline Storey No. & Solid brick infill walls \\
\hline 10 & $6.4 \times 10^{-4}$ \\
\hline 9 & $6.08 \times 10^{-4}$ \\
\hline 8 & $5.68 \times 10^{-4}$ \\
\hline 7 & $1.21 \times 10^{-3}$ \\
\hline 6 & $1.61 \times 10^{-3}$ \\
\hline 5 & $6.88 \times 10^{-4}$ \\
\hline 4 & $8 \times 10^{-4}$ \\
\hline 3 & $5.11 \times 10^{-4}$ \\
\hline 2 & $4 \times 10^{-4}$ \\
\hline 1 & $1.69 \times 10^{-3}$ \\
\hline
\end{tabular}

3.2 Comparison of Maximum Deflection in A 3 Bay

\section{Storied Building With And Without Infills}

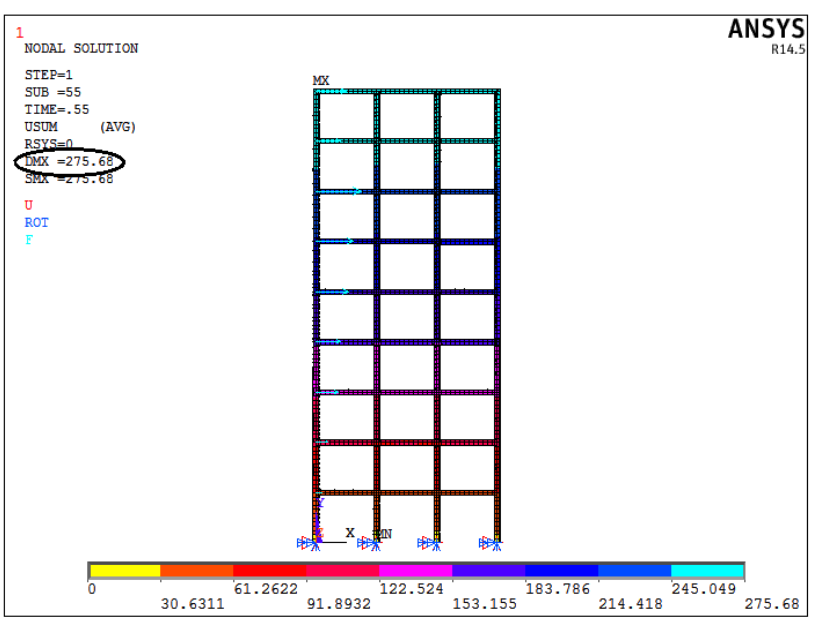

Fig -5: Maximum deflection in nine storied bare frame 


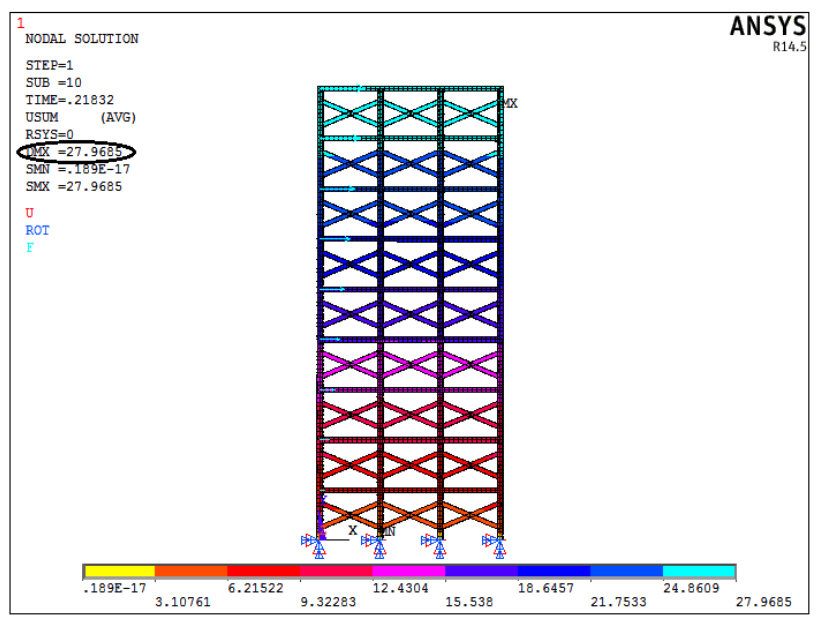

Fig -6: Maximum deflection in nine storied frame with infills

Table -3: Comparison of maximum deflection in each

\begin{tabular}{|l|l|l|l|}
\hline $\begin{array}{l}\text { Storey } \\
\text { No. }\end{array}$ & $\begin{array}{l}\text { Maximum } \\
\text { deflection } \\
\text { in bare } \\
\text { frame }\end{array}$ & $\begin{array}{l}\text { Maximum } \\
\text { deflection in } \\
\text { building with } \\
\text { solid brick } \\
\text { infills ( mm) }\end{array}$ & $\begin{array}{l}\text { \% decrease in } \\
\text { deflection of } \\
\text { SBIW with } \\
\text { reference to } \\
\text { Bare frame }\end{array}$ \\
\hline 9 & 275.6 & 27.96 & 31.86 \\
\hline 8 & 256.3 & 24.23 & 33.15 \\
\hline 7 & 211.4 & 21.11 & 28.04 \\
\hline 6 & 167.5 & 19.61 & 26.21 \\
\hline 5 & 123.9 & 15.23 & 25.08 \\
\hline 4 & 106.3 & 13.63 & 32.28 \\
\hline 3 & 76.4 & 11.32 & 36.48 \\
\hline 2 & 59.6 & 8.49 & 38.39 \\
\hline 1 & 42.6 & 6.2 & 61.19 \\
\hline
\end{tabular}

Table -4: Storey drift in a 9 storied frame

\begin{tabular}{|c|c|}
\hline Storey No. & Solid brick infill walls \\
\hline 9 & $1.06 \times 10^{-3}$ \\
\hline 8 & $8.91 \times 10^{-4}$ \\
\hline 7 & $4.28 \times 10^{-4}$ \\
\hline 6 & $1.25 \times 10^{-3}$ \\
\hline 5 & $4.57 \times 10^{-4}$ \\
\hline 4 & $6.6 \times 10^{-4}$ \\
\hline 3 & $8.08 \times 10^{-4}$ \\
\hline 2 & $6.54 \times 10^{-4}$ \\
\hline 1 & $1.77 \times 10^{-3}$ \\
\hline
\end{tabular}

\subsection{Comparison of Maximum Deflection in A 3 Bay} 8 Storied Building With And Without Infills

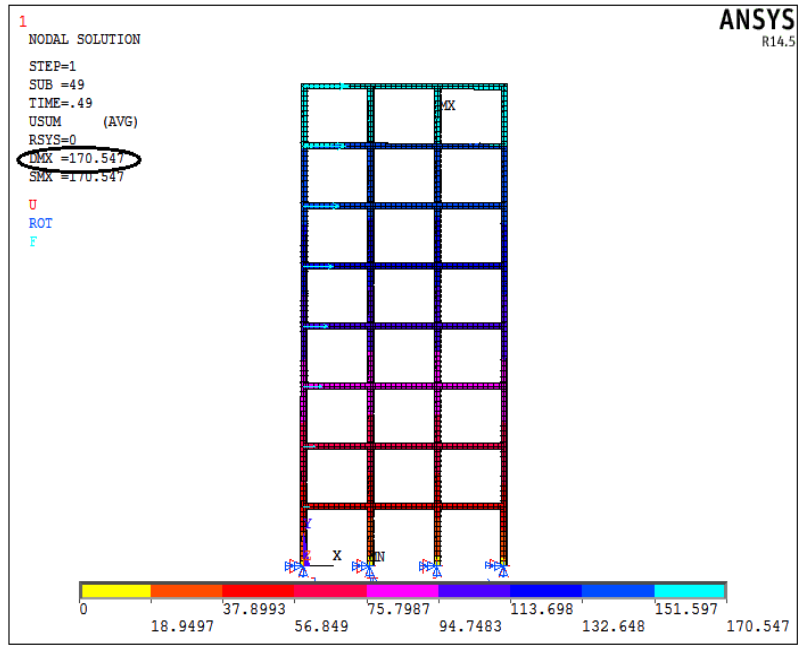

Fig -7: Maximum deflection in eight storied bare frame

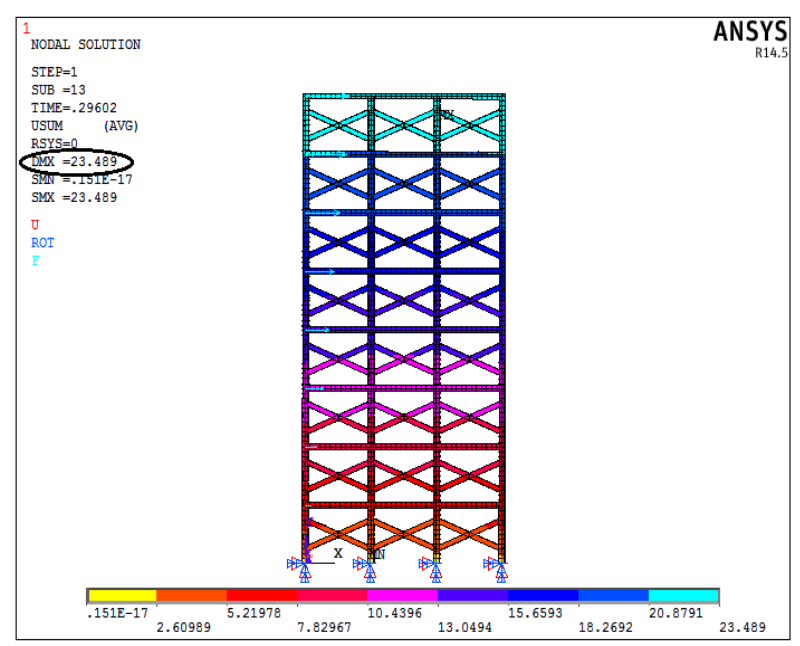

Fig -8: Maximum deflection in eight storied frame with infills

Table -5: Comparison of maximum deflection in each

\begin{tabular}{|l|l|c|c|}
\hline $\begin{array}{l}\text { Storey } \\
\text { No. }\end{array}$ & $\begin{array}{l}\text { Maximum } \\
\text { deflection in } \\
\text { bare frame }\end{array}$ & $\begin{array}{l}\text { Maximum } \\
\text { deflection in } \\
\text { building with } \\
\text { solid brick } \\
\text { infills ( mm) }\end{array}$ & $\begin{array}{l}\text { \% decrease in } \\
\text { deflection of } \\
\text { SBIW with } \\
\text { reference to } \\
\text { Bare frame }\end{array}$ \\
\hline 8 & 170.5 & 23.48 & 86.22 \\
\hline 7 & 152.5 & 20.11 & 86.81 \\
\hline 6 & 114.5 & 17.32 & 84.87 \\
\hline 5 & 100.6 & 14.91 & 85.17 \\
\hline 4 & 94.5 & 11.43 & 87.9 \\
\hline 3 & 83.6 & 9.19 & 89 \\
\hline 2 & 63.56 & 7.63 & 87.99 \\
\hline 1 & 36.83 & 5.32 & 85.5 \\
\hline
\end{tabular}


Table -6: Storey drift in an 8 storied frame

\begin{tabular}{|c|c|}
\hline Storey No. & Solid brick infill walls \\
\hline 8 & $9.62 \times 10^{-4}$ \\
\hline 7 & $7.97 \times 10^{-4}$ \\
\hline 6 & $6.88 \times 10^{-4}$ \\
\hline 5 & $9.94 \times 10^{-4}$ \\
\hline 4 & $6.4 \times 10^{-4}$ \\
\hline 3 & $4.45 \times 10^{-4}$ \\
\hline 2 & $6.6 \times 10^{-4}$ \\
\hline 1 & $1.52 \times 10^{-3}$ \\
\hline
\end{tabular}

\subsection{Comparison of Maximum Deflection in A 3 Bay}

\section{Storied Building With And Without Infills}

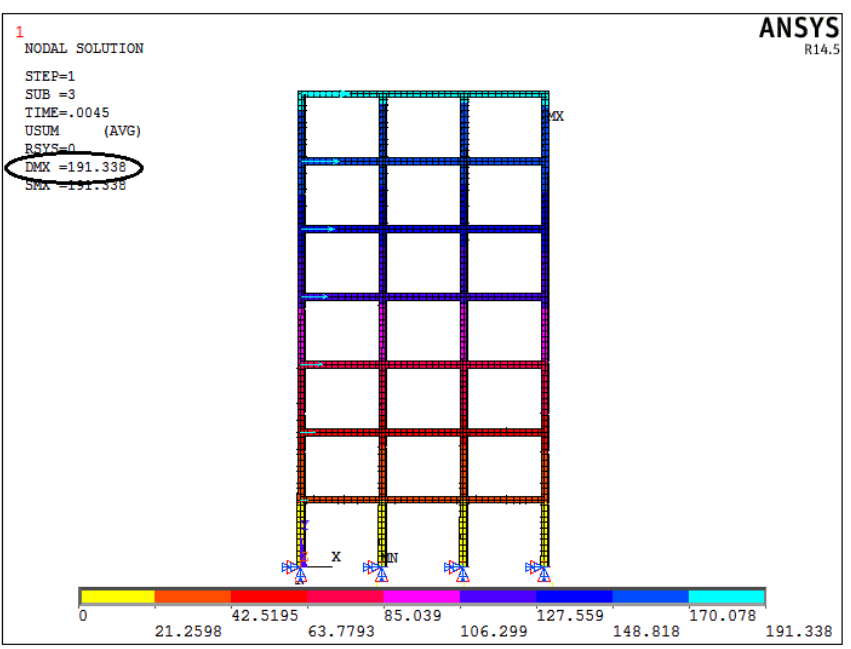

Fig -9: Maximum deflection in seven storied bare frame

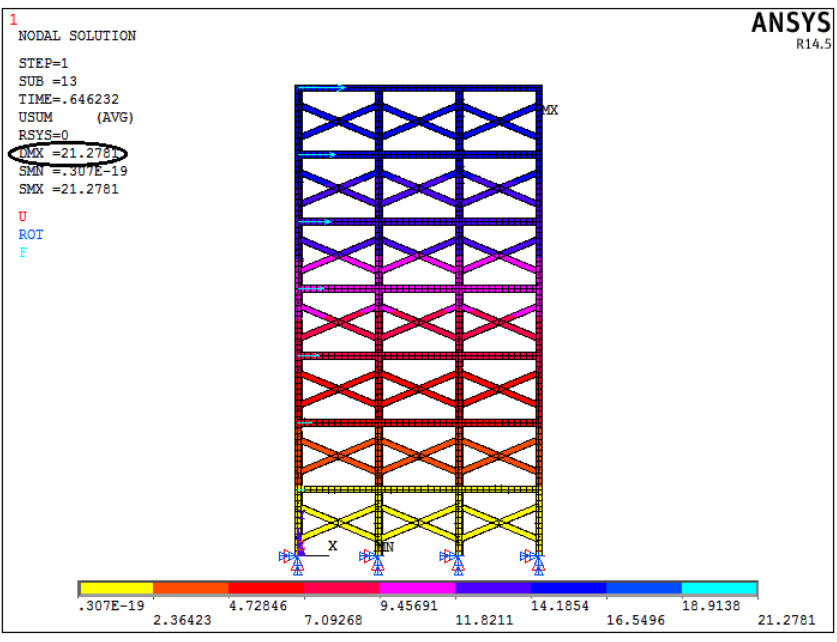

Fig -10: Maximum deflection in seven storied frame with infills
Table -7: Comparison of maximum deflection in each storey

\begin{tabular}{|c|c|c|c|}
\hline $\begin{array}{c}\text { Storey } \\
\text { No. }\end{array}$ & $\begin{array}{c}\text { Maximum } \\
\text { deflection } \\
\text { in bare } \\
\text { frame }\end{array}$ & $\begin{array}{c}\text { Maximum } \\
\text { deflection in } \\
\text { building with } \\
\text { solid brick } \\
\text { infills ( mm) }\end{array}$ & $\begin{array}{c}\text { \% decrease in } \\
\text { deflection of } \\
\text { SBIW with } \\
\text { reference to } \\
\text { Bare frame }\end{array}$ \\
\hline 7 & 191.3 & 21.27 & 88.8 \\
\hline 6 & 173.8 & 18.11 & 89.5 \\
\hline 5 & 143.6 & 15 & 89.5 \\
\hline 4 & 112.6 & 11.32 & 89.9 \\
\hline 3 & 98.65 & 8.01 & 91.8 \\
\hline 2 & 54.6 & 5.91 & 78.3 \\
\hline 1 & 32.1 & 2.3 & 92.8 \\
\hline
\end{tabular}

Table -8: Storey drift in a 7 storied frame

\begin{tabular}{|c|c|}
\hline Storey No. & Solid brick infill walls \\
\hline 7 & $9.02 \times 10^{-4}$ \\
\hline 6 & $8.88 \times 10^{-4}$ \\
\hline 5 & $1.05 \times 10^{-3}$ \\
\hline 4 & $9.45 \times 10^{-4}$ \\
\hline 3 & $6 \times 10^{-4}$ \\
\hline 2 & $1.03 \times 10^{-3}$ \\
\hline 1 & $6.57 \times 10^{-4}$ \\
\hline
\end{tabular}

3.5 Comparison of Maximum Deflection in A 3 Bay 6 Storied Building With And Without Infill

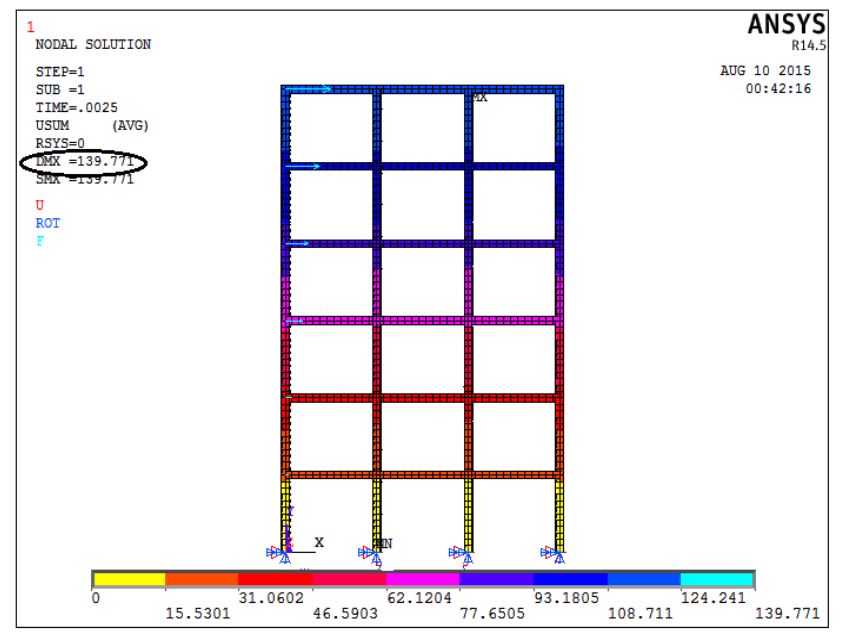

Fig -9: Maximum deflection in eight storied bare frame 


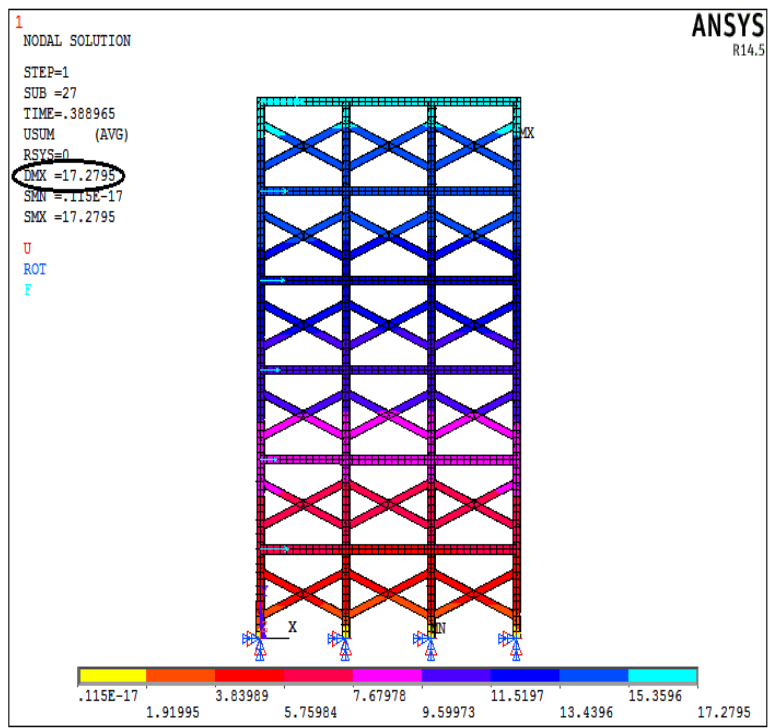

Fig -10: Maximum deflection in six storied frames with infills

Table -9: Comparison of maximum deflection in each

\begin{tabular}{|c|c|c|c|}
\hline Storey No. & $\begin{array}{l}\text { Maximum } \\
\text { deflection in } \\
\text { bare frame }\end{array}$ & $\begin{array}{l}\text { Maximum } \\
\text { deflection in } \\
\text { building with } \\
\text { solid brick } \\
\text { infills ( mm) }\end{array}$ & $\begin{array}{l}\text { \% decrease in } \\
\text { deflection of } \\
\text { SBIW with } \\
\text { reference to } \\
\text { Bare frame }\end{array}$ \\
\hline 6 & 139.77 & 17.27 & 87.6 \\
\hline 5 & 109.4 & 13.14 & 87.98 \\
\hline 4 & 98.3 & 10.32 & 89.5 \\
\hline 3 & 71.5 & 7.34 & 89.73 \\
\hline 2 & 49.24 & 5.91 & 87.99 \\
\hline 1 & 20.33 & 3.1 & 84.75 \\
\hline
\end{tabular}

Table -10: Storey drift in a 6 storied frame

\begin{tabular}{|c|c|}
\hline Storey No. & Solid brick infill walls \\
\hline 6 & $1.18 \times 10^{-3}$ \\
\hline 5 & $8.05 \times 10^{-4}$ \\
\hline 4 & $8.51 \times 10^{-4}$ \\
\hline 3 & $4.08 \times 10^{-4}$ \\
\hline 2 & $8.02 \times 10^{-4}$ \\
\hline 1 & $8.85 \times 10^{-4}$ \\
\hline
\end{tabular}

\subsection{Comparison of Maximum Deflection in A 3 Bay} 5 Storied Building With And Without Infills

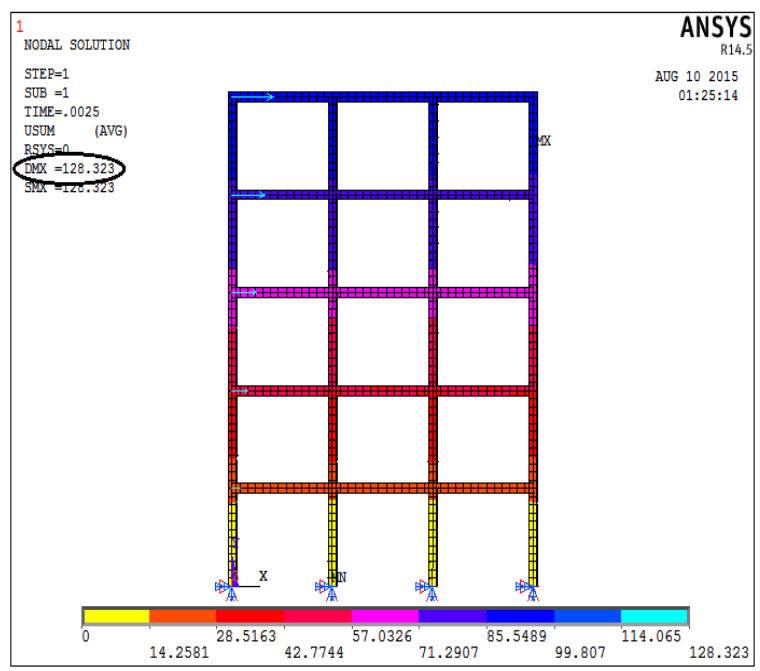

Fig -11: Maximum deflection in five storied bare frame

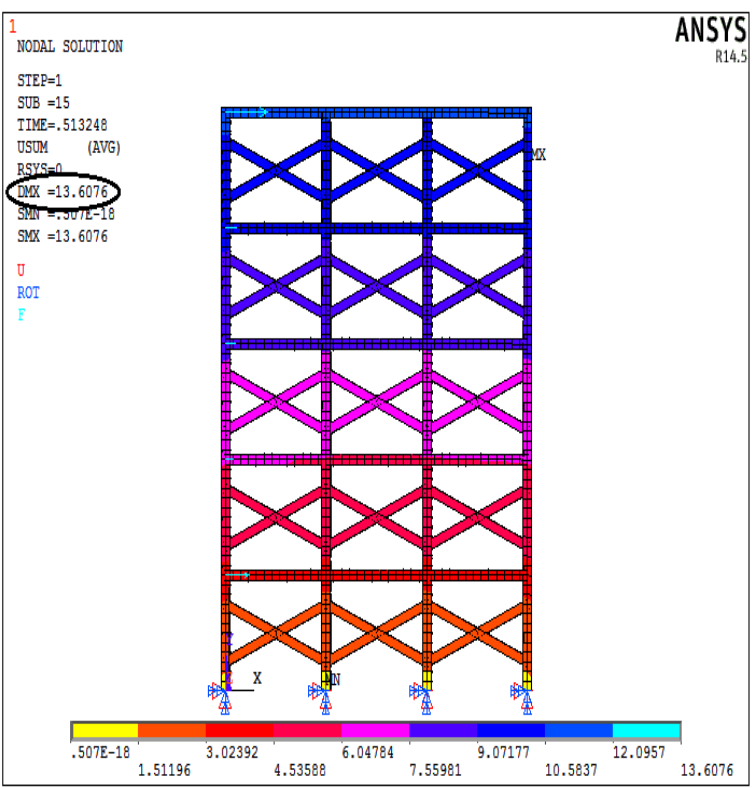

Fig -12: Maximum deflection in five storied frame with infills

Table -11: Comparison of maximum deflection in each storey

\begin{tabular}{|c|c|c|c|}
\hline $\begin{array}{c}\text { Storey } \\
\text { No. }\end{array}$ & $\begin{array}{c}\text { Maximum } \\
\text { deflection } \\
\text { in bare } \\
\text { frame }\end{array}$ & $\begin{array}{c}\text { Maximum } \\
\text { deflection in } \\
\text { building with } \\
\text { solid brick } \\
\text { infills ( mm) }\end{array}$ & $\begin{array}{c}\text { \% decrease in } \\
\text { deflection of } \\
\text { SBIW with } \\
\text { reference to } \\
\text { Bare frame }\end{array}$ \\
\hline 5 & 128.32 & 13.6 & 89.4 \\
\hline 4 & 94.5 & 10.01 & 89.4 \\
\hline 3 & 62.6 & 8.44 & 86.51 \\
\hline 2 & 36.7 & 6.46 & 82.3 \\
\hline 1 & 14.25 & 3.04 & 78.66 \\
\hline
\end{tabular}


Table.12. Storey drift in 5 storied frame

\begin{tabular}{|l|l|}
\hline Storey No. & Solid brick infill walls \\
\hline 5 & $1.02 \times 10^{-3}$ \\
\hline 4 & $4.48 \times 10^{-4}$ \\
\hline 3 & $5.65 \times 10^{-4}$ \\
\hline 2 & $9.77 \times 10^{-4}$ \\
\hline 1 & $8.68 \times 10^{-4}$ \\
\hline
\end{tabular}

\section{CONCLUSIONS}

From the seismic analysis following conclusions are drawn

- Equivalent diagonal strut method can be adopted for modelling Brick infill walls.

- 3D Analysis gives more realistic values of deflection and stresses. Since this type of study is not feasible in terms of analysis time taken, we have adopted 2D model for the present study.

- Deflection in case of bare frame is very large, when compared to solid brick infill conditions.

* Effect of number of Storey

$\checkmark$ As number of Stores increases, there are additional lateral acting loads added for increased story level. As a result, the maximum top deflection of the building increases gradually.

$\checkmark \quad$ The maximum deflection of each stores are very much reduced when infill wall panels are used.

\section{SCOPE OF FUTURE WORKS}

The present study may be regarded as a preliminary work for an extensive research work on the effect of various parameters on infilled frames due to lateral loading. The recommendations are

- Instead of solid brick infills other types of infills such as concrete block can also be considered for such type of investigation.

- $\quad$ This analysis may be performed by considering

1. Effect of number of bays

2. Effect of various spans of bay

3. Effect of various geometrical properties of beams, columns and infills.

\section{REFERENCES}

[1] Cemalettin Dönmez and M. Alper Çankaya "Effect of Infill Walls on the Drift Behavior of Reinforced Concrete Frames Subjected to Lateral-Load Reversals", Journal of Earthquake Engineering, Volume 17, Issue 5, 2013

[2] Kashif Mahmud, Rashadul Islam and Al-Amin "Study of the Reinforced Concrete Frame with Brick Masonry Infill due to lateral loads", International Journal of Civil and Environmental Engineering, Volume 10, Issue 4, August 2010, Pages 35-40

[3] Polyakov S.V, "Masonry in Framed Buildings", Moscow, 1956.
[4] Manju G "Dynamic Analysis of Infills on RC framed Structures", International Journal of Innovative Research in Science, Engineering and Technology, Volume 3, Issue 9, September 2014, Pages 16150- 16157

[5] Matjaž Dolšek and Peter Fajfar "The effect of masonry infills on the seismic response of a four-storey reinforced concrete frame ", Journal of Engineering Structures, Volume 30, Issue 7, July 2008, Pages 1991-2001.

[6] Castro, P.T Laursen, D.C Jansen, "Performance of interlocking compressed earth block infill in confined masonry construction" Journal of Earthquake Engineering, July 2014, Pgs: 1-13

[7] S. Pujol and D. Fick, "The test of a full-scale three-story RC structure with masonry infill walls", Science Direct, Volume 32, Issue 10, October 2010, Pages 3112-3121

[8] A. Madan, and M. Reinhorn, " Modeling of masonry infill panels for structural analysis" Journal of Structural Engineering,2011, pages:1295-1302 